\title{
COMMITTEE ON FOREST PATHOLOGY
}

In closing this report your Committee wishes to stress the importance of the forest-fire research work heing carried on in Canada and the necessity for the fullest financial support on the part of federal and provincial authorities.

$$
\begin{aligned}
& \text { Respectfully submitted, } \\
& \text { H. METHOT, Chairnan. } \\
& \text { J. G. WRIGHT, Secretary. }
\end{aligned}
$$

Mr. Macdonald stressed the importance of investigating fire-fighting equipment with a view to improving efficiency. He hoped that it would be possible to obtain publicity for fire-prevention by short radio bulletins next summer.

Mr. Miller stated that fire-bulletins had been broadcast at the same time as the weather forecasts by two stations in the east last year, and had proved very successful.

Mr. Hutchison endorsed Mr. Macdonald's proposals regarding the broadcasting of fire bulletins.

Mr. Macdonald mentioned the lack of uniformity in the methods of compiling fire statistics used by some provinces. Mr. Crosby stated that in Ontario it had been found that newspaper bulletins describing the fire-hazard situation had in some cases had a detrimental effect on tourist trade.

Mr. Kilby suggested changing the time of fire-prevention week from October 11 th to a date more representative of the forest fire season.

$\mathrm{Mr}$. Riley read the report of the Sub-Committee on Forest Pathology.

\section{SUB-COMMITTEE ON FOREST PATHOLOGY, FOREST RESEARCH CO-OPERATION COMMITTEE, CANADIAN SOCIETY OF FOREST ENGINEERS}

$$
\text { Report to the Annual Meeting, C.S.F.E., Janunry, } 1937
$$

The principal aim of forest pathology is to investigate unhealthy conditions of trees, and to thereby discover means of preventing or reducing losses due to them. Within this field of investigation may be mentioned such examples as heartrots, cankers, leaf diseases, diseases of nursery stock, deterioration of timber killed by fire or insects, etc. Such conditions are commonly the results of attacks by fungi, but some are also due to other causes, as bacteria, and such non-parasitic agencies as fumes from industrial operations, drought, frost, improper water relations, etc. In short, forest pathology embraces the study of practically all diseased conditions of trees, except injuries caused directly by insects, which come within the field of forest entomology. A special branch of forest pathology deals with deterioration in forest products, as lumber, structural timber, pulpwood, pulp, etc. 
Research in forest pathology is conducted in Canada by federal and provincial government organizations and by universities. The research projects may be divided into the following two categories: (1) Those having a direct, economic bearing, with the primary object of obtaining information that will be useful in avoiding losses due to disease; (2) Those which, while no direct, economic bearing may be apparent, are nevertheless important as steps leading to a thorough understanding of the former class of problem. They embrace the basic or fundamental research projects which are essential to a thorough understanding of any problem. Naturally, the second category is by far the greater. It is also the less appreciated and understood by the layman, a fact that adds considerably to the difficulties of winning support for basic research. Forest pathologists recognize, however, that from the vast field of problems that await attention, first consideration should be given, where possible, to those, the solution of which is likely to yield the highest and earliest returns to forestry.

The sub-committee on Forest Pathology proposes to establish a service with the following primary objectives:

(1) The building up of a list of references to published articles dealing with problems in forest pathology, having possible applications in Canada. A great deal of valuable information has been published, which could and should be profitably used in the various activities connected with our forest industries. That greater use is not made of this information, is due largely to the fact that many of those who might otherwise benefit by it are either unaware of its existence, or do not know where to find it. An annotated reference list published in the "Chronicle" and added to annually, would provide a convenient means of overcoming this difficulty.

(2) A survey of problems in forest pathology awaiting attention, these to be considered as to their economic aspects and urgency, with the final object of determining which should receive first attention. Research in forest patho$\operatorname{logy}$ in Canada is at present conducted on a very limited scale, and consequently only a few problems can be given attention at the same time. Further, many problem are of such a nature that two or three or more years of study are necessary to bring them to completion. It is obviously important, therefore, that great care should be taken in deciding upon which of the many that exist, should be undertaken next. The results of this survey would be of considerable value to forest pathologists.

(3) Recommendations to research organizations, that the more important problems in forest pathology be undertaken with the least possible delay. The choice of problems for study, is of course, a matter to be decided by the respective research organizations, and is of necessity, governed largely by circumstances within the organization, such as personnel, time, and funds that 
can be allotted to a given project. Undoubtedly, however, recommendations of an organization representing all phases of the forest industries, as does the C.S.F.E., would bear considerable weight in determining whether or not provision will be made for the study of any given problem.

(4) A survey of research projects in forest pathology already being conducted, or planned. This would serve as useful means of contact between forest pathologists, and would provide them with a means of keeping informed as to what problems are being studied, thus helping to avoid duplication, and promoting co-operation, and co-ordination of research.

Due to a number of circumstances, the Sub-Committee on Forest Pathology did not succeed in getting actively under way till the autumn of 1936, and is, therefore, still in the process of organization. However, activities have now begun in accordance with the plan outlined above. The Sub-Committee at present consists of members residing in various parts of the Dominion, as follows:

G. W. I. Creighton, Dept. of Lands \& Forests, Halifax, N.S. Otto Schierbeck, Ottawa, (representing Maritime Provinces.)

R. E. Balch, Dominion Entomological Branch, Fredericton, N.B.

L. S. Webb, N.B. International Paper Co. Ltd. Campbellton, N.B.

J. O. Wilson, Anglo-Canadian Pulp \& Paper Mills, Quebec, Que.

D. D. Mix, Can. International Paper Co. Ltd. Maniwaki, Que.

J. D. B. Harrison, Dominion Forest Service, Ottawa (Representing Prairie Provinces).

C. C. Heimburger, Dominion Forest Service, Ottawa.

W. R. Haddow, Ontario Forest Branch, Toronto.

J. E. Bier, Forest Pathological Service, Central Experimental Farm, Ottawa

A. W. McCallum, Forest Pathological Service, Central Experimental Farm, Ottawa

C. G. Riley (Chairman), Forest Pathological Service, Central Experimental Farm, Ottawa.

J. B. Millar, Spruce Falls P. \& P. Co. Ltd. Kapuskasing, Ont.

N. M. Ross, Forest Nursery Station, Indian Head, Sask.

E. H. Garman, B. C. Forest Service, Victoria, B.C.

Other members will be added to the list whenever this seems advisable. Each member is urged to attempt to interest one or more others in his vicinity in order that he may have the advantage of being able to discuss with them matters of interest to the Sub-Committee. All members are requested to submit any information relative to the objects of the Sub-Committee as already outlined. Already a number of good suggestions have been received from members and the Sub-Committee has been able to supply information re- 
quested regarding problems in forest pathology. For example, a report dealing with the poplar canker problem in the Prairie Provinces has come to light as a result of correspondence regarding a request for information in this matter. Similarly, attention of another member has been directed to published information regarding heart rots in balsan fir. It is believed that the SubCommittee can serve a useful purpose in this manner.

A good beginning has been made on the compilation of a reference list, the first section of which will be made available within the year.

Mr. Riley moved the adoption of the report. Mr. Macdonald seconded.

$\mathrm{Mr}$. Schierbeck said he thought fungi were destroying more timber than was lost by forest fires in Canada. He belicved there were not sufficient forest pathologists in Canada, and suggested that the Socicty should go on record as favouring increased appropriations for work in forest pathology.

$\mathrm{Mr}$ : Riley said his Sub-Committee was going to prepare a list of projects demanding attention, and then, he thought, the Society and forestry authorities in general would have a better case for asking for increased financial support.

Dr. Heimburger helieved softwood diseases were more important than those of hardwood, and considered more work should be done in developinent of cull factors for diseased trees.

The President stressed the importance of balsam rots which were the cause of a great deal of loss and a source of much trouble. He said this was particularly important in view of the fact that balsam is most prevalent type of reproduction on cut-over lands.

Mr. Robertson suggested that soil experts and pathologists should cooperate in the work on balsain rot as he felt that site was a very important factor.

Mr. McElhanncy supported Mr. Riler in the belief that the monetary losses from pathological causes should be determined so that the case for increased appropriations would be strengthened.

Mr. Riley pointed out the wide divergence in the methods commonly used in estimating cull. He believed culls were really a problem of utilization as much as of pathology hecause much sound wood was discarded in culled logs.

The President said the flotation of partially rotten balsam presented a very serious problem indeed, quite apart from the destruction of the wood by the decay itself.

Before adjournment the President appointed the following members to form the Resolutions Committee: Jenkins, Davidson, Miller, Andrews and Watt.

The meeting adjourned at 5:15 P.M. 